\title{
Soybean as supplement of growing cattle on tropical pasture. Effects on intake, digestibility and animal performance
}

\author{
Balbuena, O. ; Rochinotti, D. ${ }^{2}$; Kucseva, C.D. ${ }^{1}$; Slanac, A.L. ${ }^{3}$; Kudo, H. ${ }^{4}$ \\ 'Instituto Nacional de Tecnología Agropecuaria (INTA), Colonia Benitez, Chaco, Argentina; ${ }^{2}$ INTA Mercedes, \\ Corrientes, Argentina; ${ }^{3}$ Facultad de Ciencias Veterinarias, UNNE, Corrientes, Argentina; ${ }^{4}$ Animal Production \\ and Grassland Division, Research Planning and Coordination Division, Japan International Research Center \\ for Agricultural Sciences (JIRCAS), Tsukuba, Ibaraki 305-8686, Japan. E-mail: hkudo@jircas.affrc.go.jp.
}

\begin{abstract}
Balbuena, O.; Rochinotti, D.; Kucseva, C.D.; Slanac, A.L.; Kudo, H.: Soybean as supplement of growing cattle on tropical pasture. Effects on intake, digestibility and animal performance. Rev. vet. 23: 1, 20-24, 2012. An indoor trial was conducted with weaning heifers (experiment 1). Raw whole soybean (RSB), whole soybean heated with steam (SHSB) and extruded whole soybean (EXSB) were given as supplements at $0.7 \%$ of live weight (LW). One group was the control, with no supplement. All supplements increased total dry matter (DM) intake and did not affect hay intake. RSB was the most degradable crude protein (CP) source. Total digestive tract digestibility was not affected by treatments, except for apparent CP digestibility. Because total DM intake increased in supplemented animals, all supplements increased intake of digestible DM, organic matter (OM) and CP over the control. In another assay (experiment 2) a performance trial was conducted with forty weaned heifers. The same supplements used in experiment 1 were used. Heifers supplemented with EXSB gained the highest and had better apparent feed efficiency. Apparent feed efficiency was similar to those observed in protein supplementation, suggesting that some increase in DM intake from pasture may have occurred. RSB had the poorest apparent feed efficiency which agreed with the numerical lower OM intake observed in experiment 1 . All supplemented heifers had higher gain, hip height change, thoracic perimeter and body condition score change than the control group.
\end{abstract}

Key words: beef cattle, supplemental feed, soybean, winter feeding.

\begin{abstract}
Resumen
Balbuena, O.; Rochinotti, D.; Kucseva, C.D.; Slanac, A.L.; Kudo, H.: Soja como suplemento de bovinos en crecimiento sobre pasturas tropicales. Efectos sobre el ingreso, digestibilidad y rendimiento. Rev. vet. 23: 1, 20-24, 2012. Se condujo un ensayo de consumo en confinamiento con destetes hembras en un diseño cuadrado latino $4 \times 4$ (experimento 1). Los suplementos (tratamientos) utilizados al $0,7 \%$ del peso vivo (LW) fueron: soja entera cruda (RSB), soja entera desactivada con vapor (SHSB) y soja entera extrusada (EXSB). Un cuarto tratamiento no recibió suplemento y actuó como control. Se suministró heno de pasto estrella de baja calidad ad libitum a todos los tratamientos. Todos los suplementos incrementaron el consumo total de materia seca (DM) y no afectaron el consumo de heno. La RSB tuvo la mayor degradabilidad ruminal de proteína bruta (CP). La digestibilidad aparente de las dietas no fue afectada por los tratamientos, excepto la digestibilidad aparente de CP. Debido al incremento del consumo de DM, todos los suplementos incrementaron el consumo de DM digestible, materia orgánica (OM) digestible y CP. En otra prueba (experimento 2) se utilizaron cuarenta destetes hembras para un ensayo de producción sobre pastura de Dichantium caricosun. Se utilizaron los mismos suplementos descriptos en el experimento 1. Las vaquillas suplementadas con EXSB tuvieron las mayores ganancias de peso vivo y mejor eficiencia de conversión aparente. La eficiencia de conversión aparente fue similar a las observadas cuando se suplementa con proteínas, sugiriendo que pudo haber un incremento del consumo de pasto. Las vaquillas suplementadas con RSB tuvieron la menor eficiencia de conversión aparente, en línea con el menor valor numérico de consumo de MO observada en el Expe-
\end{abstract}


rimento 1. Las vaquillas suplementadas tuvieron mayores ganancias de peso, incremento de altura a la grupa, del perímetro toráxico y de la condición corporal que las vaquillas del tratamiento testigo sin suplementación.

Palabras clave: bovinos para carne, suplementación dietaria, soja, alimentación invernal.

\section{INTRODUCTION}

Soybean production has increased in Argentina in recent years. Production grew from $11.7 \mathrm{Mt}$ in the season $1995 / 96$ to $35.5 \mathrm{Mt}$ in the season 2003/04. Grain crushing reached 21.5 Mt and whole grain (WSB) export reached $8.5 \mathrm{Mt}$. The industry exportable coefficient is $97 \%$ for soybean meal (SBM) with $16.8 \mathrm{Mt}^{9}$. That leaves ten times more WSB than SBM available for domestic consumption. About $25 \%$ of the soybean is produced far from oil factories and docks. Transportation costs favour the use of WSB as animal feed near the area where it is produced. The cost of CP is about 20 to $25 \%$ less in WSB than in SBM.

Tropical pastures are fast maturing with low $\mathrm{CP}$, low digestibility and low voluntary intake, especially during winter. Main constraints to beef production in Northern Argentina are low average daily gain (ADG) and low calving rates. To ensure that heifers are bred at two-years old, a supplementation program is often needed during the first winter after weaning. Excess pasture produced by the end of summer and early fall is consumed during winter as standing hay. A protein or protein plus energy supplement is needed to improve forage utilization ${ }^{1,3}$. The use of SBM in dairy cattle ${ }^{5}$ and soy by-products has been reviewed ${ }^{11}$. For cattle, the use of soybean hulls as an energy source has been emphasised ${ }^{11}$.

This study explores the response to different processing of WSB on intake, digestibility and heifers performance during winter.

\section{MATERIAL AND METHODS}

Experiment 1. Our group is been using an experimental model were the low quality tropical grass forage available during winter under grazing conditions is simulated with the ad libitum feeding of late cutting of Stargrass hay. The weaning cattle used were similar in breed and age as those under grazing conditions. This experimental model was useful to estimate intake of hay and supplements, digesta kinetics and digestibility of total diet ${ }^{1-3}$. It is well known that those variables are difficult to measure under grazing conditions. Furthermore, the data provides by this experimental model helped to explain results of animal performance under grazing conditions during winter.

An indoor trial was initiated in September 2003 with weaning heifers. Zebu crossbreed of eight month of age and $180 \mathrm{~kg}$ live weight were used. The objective was to evaluate the effect of different soybean process- ing on hay intake and total diet digestibility. And experimental $4 \times 4$ latin square design was used. Periods lasted 21 days and measurements were taken during the last 7 days. Low quality Stargrass hay $(3.9 \%$ CP) was fed ad libitum plus a mineral supplement to all treatments. Hay was chopped to approximately $6 \mathrm{~cm}$ and fed ad libitum twice a day (07:30 and 19:30 h), as the base diet. Supplements were fed in restricted amount at 7:00 am, after collecting hay orts and prior to offer of new hay. Supplements were RWB, SHSB $\left(110^{\circ} \mathrm{C}\right.$ for $30 \mathrm{~min}$ ) and EXSB, given at $0.7 \%$ of LW. The control treatment received hay alone. Supplement composition is presented in Table 1.

Table 1. Composition of soybean utilized (\% dry matter).

\begin{tabular}{lccc}
\hline fraction & $\begin{array}{c}\text { raw } \\
\text { soybean }\end{array}$ & $\begin{array}{c}\text { steam heated } \\
\text { soybean }\end{array}$ & $\begin{array}{c}\text { extruded } \\
\text { soybean }\end{array}$ \\
\hline crude protein & 40 & 41 & 40 \\
NDF & 26 & 27 & 22 \\
ADF & 23 & 23 & 19 \\
crude fiber & 22 & 22 & 16 \\
ether extract & 20 & 20 & 19 \\
crude ash & 7 & 8 & 6 \\
\hline
\end{tabular}

NDF: neutral detergent fiber, ADF: acid detergent fiber.

Feed intake was measured during the last week of each period, assuring a $15 \%$ hay refusal. Procedures for determining voluntary intake and digestibility in sheep ${ }^{8}$, were followed with pertinent adaptations. Spot fecal samples were taken from the rectum every 4 h during 3 days. Hay and supplement offered, hay refusal and fecal samples were dried at $60^{\circ} \mathrm{C}$ and ground through a Willey mill. Grab samples of hay were obtained, placed in air-tight plastic bags and sealed. Daily samples from a given heifer in each collection period were placed in the same bag. The total weight of the sampled hay was recorded prior to grinding. During the collection period, orts were collected prior to the morning feeding. Feeders were swept and orts collected, and transferred to woven plastic bags. Weight of orts was recorded prior to grinding.

The week following the collection period, composite hay samples were dried and ground in a hammer mill, then ground in a Wiley mill to pass 4-mm and $1-\mathrm{mm}$ screens and stored in plastic bags until analyzed. Orts from each heifer were air dried before grinding, and stored as described for samples of hay. Analysis of DM for intake calculation was performed the same day that the hay or orts were ground. Analytical DM 
Table 2. Hay, supplement and total dry matter intake.

\begin{tabular}{lcccccc}
\hline \multirow{2}{*}{ item } & \multicolumn{3}{c}{ supplement } & \multirow{2}{*}{ control } & \multirow{2}{*}{ SE } & p \\
\cline { 2 - 4 } & SHSB & RSB & EXSB & & & \\
\hline mean body weight, kg & 190 & 190 & 184 & 190 & 3.961 & 0.724 \\
\hline $\begin{array}{l}\text { intake, kg /day } \\
\text { hay }\end{array}$ & 3.57 & 3.43 & 3.45 & 3.38 & 0.12 & 0.741 \\
supplement & 1.29 & 1.35 & 1.28 & 0 & 0.02 & - \\
$\quad$ total & $4.86^{\mathrm{a}}$ & $4.78^{\mathrm{a}}$ & $4.73^{\mathrm{a}}$ & $3.38^{\mathrm{b}}$ & 0.11 & 0.0002 \\
\hline intake, \% body weight & & & & & & \\
hay & 1.88 & 1.78 & 1.87 & 1.78 & 0.053 & 0.448 \\
supplement & 0.68 & 0.71 & 0.69 & 0 & 0.011 & - \\
total & $2.56^{\mathrm{a}}$ & $2.49^{\mathrm{a}}$ & $2.56^{\mathrm{a}}$ & $1.78^{\mathrm{b}}$ & 0.050 & 0.0001 \\
\hline
\end{tabular}

SHSB: whole soybean heated with steam, RSB: raw whole soybean, EXSB: extruded whole soybean, SE: standard error, $\mathrm{p}$ : significance. ${ }^{\mathrm{ab}}$ means in a row with different letters differ $(\mathrm{p}<0.05)$.

Table 3. Total tract diet digestibility using acid insoluble ash as internal marker $(\%)$.

\begin{tabular}{lcccccc}
\hline \multirow{2}{*}{ digestibility, \% } & \multicolumn{3}{c}{ supplement } & \multirow{2}{*}{ control } & \multirow{2}{*}{ SE } & p \\
\cline { 2 - 5 } & SHSB & RSB & EXSB & & & \\
\hline dry matter & 57.7 & 54.8 & 60.2 & 58.6 & 4.04 & 0.814 \\
crude protein & $78.6^{\mathrm{a}}$ & $76.9^{\mathrm{a}}$ & $78.6^{\mathrm{a}}$ & $38.4^{\mathrm{b}}$ & 4.73 & 0.002 \\
NDF & 52.1 & 50.1 & 54.9 & 61.1 & 4.49 & 0.408 \\
ADF & 51.3 & 51.2 & 55.1 & 59.4 & 4.50 & 0.571 \\
organic matter & 59.7 & 57.1 & 62.3 & 61.6 & 3.84 & 0.782 \\
\hline
\end{tabular}

SHSB: whole soybean heated with steam, RSB: raw whole soybean, EXSB: extruded whole soybean, SE: standard error, p: significance, NDF: neutral detergent fiber, ADF: acid detergent fiber, ${ }^{\text {ab }}$ means in a row with different letters differ $(\mathrm{p}<0.05)$.

content of samples was determined by drying at $105^{\circ} \mathrm{C}$ overnight. The $\mathrm{OM}$ was calculated as the difference between dry matter and ash content, with ash content determined by combustion at $550^{\circ} \mathrm{C}$.

Total nitrogen content was determined by the Kjeldahl method and crude protein content was calculated as nitrogen $x$ 6.25. Neutral detergent fiber (NDF) was analyzed by the method by Goering and Van Soest 4 with the exception that sodium sulphite was omitted. Acid detergent fiber (ADF) was measured by the method by Goering and Van Soest ${ }^{4}$. Acid insoluble ash was determined using $2 \mathrm{~N} \mathrm{HCl}$ as described by Van Keulen and Young ${ }^{12}$. Blood samples were drawn from the jugular vein at $4 \mathrm{~h}$ after feeding the supplement for blood serum urea-N analysis. As supplement intake was fast and complete in all supplements, it is assumed that the serum urea- $\mathrm{N}$ values can be compared because the time of sampling was fixed. Statistic analysis was conducted using SAS ${ }^{10}$, with animal, period and treatments in the model.

Experiment 2 (effects on performance). A performance trial was conducted from May to October, 2003. Forty weaned heifers zebu crossbreed were used. Heifers were allocated to four treatments: Control (pasture alone), and the same supplements used in Experiment 1 (Table 1). Supplements were group-fed and given at
$0.7 \%$ of initial LW. Pasture was Dichantium caricosun stockpiled to assure that pasture availability was not limiting for voluntary intake. The winter was dry, with $40 \%$ of the average rainfall for that time of the year. Stocking rate was 1.5 heifer/ha and average DM offered was 2.1, 1.6 and 1.2 tons of DM/heifer in July, August and October, respectively. This total DM offered would suggest that DM availability was not limiting for $a d$ libitum intake. There were four adjacent paddocks of pastures.

Every week, heifers of each treatment were rotated clockwise to minimize the possible differences among paddocks. As result of that, each of the four treatment remained at each paddock between sampling and weighing dates. At the beginning and at the end of the experiment, full and shrunk weight, hip height, thoracic perimeter and body condition score (1 to 9) were recorded. Every $28 \mathrm{~d}$, full weight was also recorded. Jugular blood samples were taken on four weighing days and serum was separated for urea analysis. Statistic analysis was performed using SAS ${ }^{10}$, taking the animal as the experimental unit. Effects on the model were: treatment, breed (more Zebu or more Hereford type) and their interactions. Blood urea analyses were analysed as split-plot in time. Because there was a date of sampling by treatment interaction $(\mathrm{p}<0.05)$, an analysis by date was performed using treatment in the model.

\section{RESULTS AND DISCUSSION}

Experiment 1. All supplements increased total dry matter intake and did not affect hay intake, thus the effect of soybean supplementation at the level used can be considered as additive as substitution was not

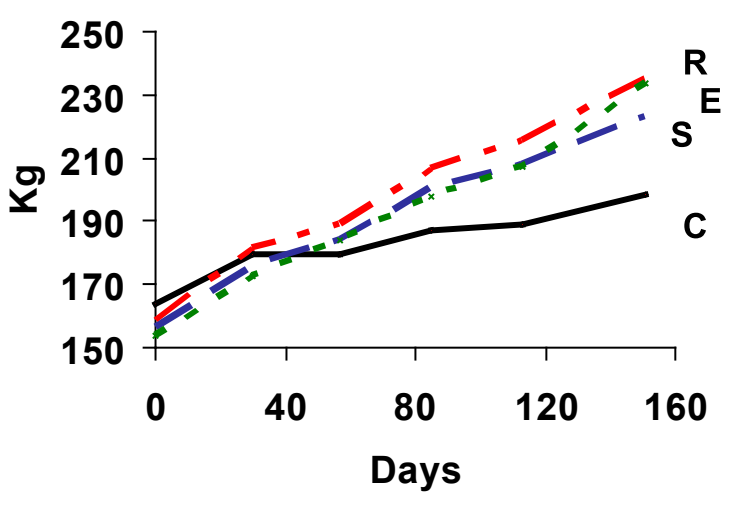

Figure 1. Live weight by treatment. C: control, R: raw whole soybean, S: whole soybean heated with steam, E: extruded whole soybean. 
observed (Table 2). However, our group found an increase in hay intake when a similar type of low quality hay was supplemented with $400 \mathrm{~g}$ of CP from SBM or cottonseed meal (CSM) ${ }^{2}$.

When whole cottonseed (WCS) was given at $0.45 \%$ of $\mathrm{LW}$ to growing cattle, an increase of hay intake of $0.15 \%$ of LW was observed ${ }^{7}$. Different response of hay intake may be related to the oil content in soybean when compared to SBM or CSM and to supplementation level when compared to WCS. Thus it is possible that the effect of stimulation of hay intake by protein was of similar magnitude to the inhibitory effect of hay intake by oil. No change in hay intake was observed when WCS was supplemented with $0.45 \%$ of $\mathrm{LW}^{7}$.

Means of serum urea-N were $(\mathrm{mg} /$ dl): $17.9^{\mathrm{a}}, 19.5^{\mathrm{b}}, 17.3^{\mathrm{a}}$ and $8.1^{\mathrm{c}}$ for SHSB, RSB, EXSB and control, respectively. Those numbers indicate that $\mathrm{N}$ was limiting for normal ruminal function in control animals. RSB was the most rumen degradable CP source of the three tested, which agree with the highest serum urea$\mathrm{N}$ value.

Total tract digestibility was not affected by treatments, except for apparent CP digestibility, which was expected (Table 3). The main effect of protein supplements seen by our group using the same experimental model described in experient 1 was increase in hay intake with small or no changes in OM and NDF digestibility, perhaps due to a decrease of about $10 \mathrm{~h}$ in total tract retention time ${ }^{2}$ . Because total DM intake increased in supplemented animals, all supplements increased intake of digestible DM, OM and $\mathrm{CP}$ over the control (Table 4).

Experiment 2. Initial and performance data are presented in Table 5, and evolution of full weight is presented in Figure 1. Heifers supplemented with EXSB gained more than the ones fed the other supplements and had better apparent feed efficiency. Apparent feed efficiency was similar to those observed in protein supplementation, suggesting that some increase in DM intake from pasture may have occurred. Whole row soybean had the poorest apparent feed efficiency which agreed with the numerical lower DM intake observed in experiment 1 . All supplemented heifers had higher gain, hip height change, thoracic perimeter and body condition score change than the control ones (Table 5).

The serum urea-N concentration (Table 6) suggested that ruminal ammonia- $\mathrm{N}$ was not limiting for bacte-
Table 4. Intake of apparent digestible fractions ( $\mathrm{kg}$ per day).

\begin{tabular}{lcccccc}
\hline \multirow{2}{*}{ fraction } & \multicolumn{3}{c}{ supplement } & \multirow{2}{*}{ control } & \multirow{2}{*}{ SE } & p \\
\cline { 2 - 6 } & SHSB & RSB & EXSB & & & \\
\hline dry matter & $2.81^{\mathrm{a}}$ & $2.58^{\mathrm{a}}$ & $2.85^{\mathrm{a}}$ & $1.96^{\mathrm{b}}$ & 0.168 & 0.032 \\
crude protein & $0.53^{\mathrm{a}}$ & $0.51^{\mathrm{a}}$ & $0.51^{\mathrm{a}}$ & $0.05^{\mathrm{b}}$ & 0.015 & 0.0001 \\
NDF & 1.59 & 1.48 & 1.60 & 1.53 & 0.124 & 0.898 \\
$\mathrm{ADF}$ & 1.06 & 1.06 & 1.12 & 0.54 & 0.235 & 0.353 \\
organic matter & $2.71^{\mathrm{a}}$ & $2.51^{\mathrm{a}}$ & $2.76^{\mathrm{a}}$ & $1.91^{\mathrm{b}}$ & 0.144 & 0.020 \\
\hline diet CP, \%DM & $13.92^{\mathrm{a}}$ & $13.96^{\mathrm{a}}$ & $13.76^{\mathrm{a}}$ & $3.80^{\mathrm{b}}$ & 0.40 & 0.0001 \\
\hline
\end{tabular}

SHSB: whole soybean heated with steam, RSB: raw whole soybean, EXSB: extruded whole soybean, SE: standard error, p: significance, NDF: neutral detergent fiber, ADF: acid detergent fiber, CP: crude protein, DM: dry matter, ${ }^{a b}$ means in a row with different letters differ $(\mathrm{p}<0.05)$.

Table 5. Initial and performance data.

\begin{tabular}{|c|c|c|c|c|c|c|}
\hline \multirow{2}{*}{ variable } & \multicolumn{3}{|c|}{ supplement } & \multirow{2}{*}{ control } & \multirow{2}{*}{ SE } & \multirow{2}{*}{$\mathrm{p}$} \\
\hline & SHSB & RSB & EXSB & & & \\
\hline \multicolumn{7}{|l|}{ initial: } \\
\hline shrunk LW, kg & 153.5 & 148.3 & 150.2 & 154.4 & 6.74 & 0.74 \\
\hline thoracic perim., $\mathrm{cm}$ & 126.2 & 125.3 & 127.2 & 126.8 & 2.39 & 0.98 \\
\hline hip height, $\mathrm{cm}$ & 105.3 & 107.1 & 105.5 & 104.9 & 1.61 & 0.59 \\
\hline $\mathrm{BC}$, score & 4.58 & 4.21 & 4.54 & 4.39 & 0.16 & 0.34 \\
\hline \multicolumn{7}{|l|}{ performance: } \\
\hline ADG, g/day & $433^{\mathrm{a}}$ & $388^{\mathrm{a}}$ & $511^{\mathrm{b}}$ & $180^{\mathrm{c}}$ & 21 & 0.001 \\
\hline$\Delta$ hip height, $\mathrm{cm}$ & $15.8^{\mathrm{a}}$ & $15.2^{\mathrm{a}}$ & $16.6^{\mathrm{a}}$ & $6.25^{\mathrm{b}}$ & 1.53 & 0.001 \\
\hline$\Delta$ thoracic perim., $\mathrm{cm}$ & $11.5^{\mathrm{ab}}$ & $10.3^{\mathrm{a}}$ & $13.3^{\mathrm{b}}$ & $7.2^{\mathrm{c}}$ & 0.68 & 0.001 \\
\hline$\Delta \mathrm{BC}$, score & $0.79^{\mathrm{a}}$ & $1.38^{\mathrm{ab}}$ & $1.63^{\mathrm{b}}$ & $-0.08^{c}$ & 0.23 & 0.001 \\
\hline supplement DM, kg/day & 1.02 & 1.11 & 1.09 & 0 & na & na \\
\hline $\mathrm{kg}$ supplem./kg added gain & 4.11 & 5.29 & 3.51 & - & na & na \\
\hline
\end{tabular}

SHSB: whole soybean heated with steam, RSB: raw whole soybean, EXSB: extruded whole soybean, SE: standard error, p: significance, LW: live weight, BC: body condition score (1 to 9 scale), ADG: average daily gain, DM; dry matter, na = not applicable because heifers were group feeding, ${ }^{\text {ab }}$ means in a row with different letters differ $(p<0.05)$.

Table 6. Serum urea nitrogen by sampling date and treatments (mg/dl).

\begin{tabular}{lcccccc}
\hline \multirow{2}{*}{ date } & \multicolumn{3}{c}{ supplements } & \multirow{2}{*}{ control } & SE & \multirow{2}{*}{$\mathrm{p}$} \\
\cline { 2 - 6 } & SHSB & RSB & EXSB & & & \\
\hline june 2 & $17.3^{\mathrm{a}}$ & $20.8^{\mathrm{b}}$ & $14.3^{\mathrm{c}}$ & $5.1^{\mathrm{d}}$ & 0.50 & 0.0001 \\
july 3 & $20.5^{\mathrm{a}}$ & $20.4^{\mathrm{a}}$ & $14.5^{\mathrm{b}}$ & $4.4^{\mathrm{c}}$ & 1.10 & 0.0001 \\
july 31 & $20.8^{\mathrm{a}}$ & $24.2^{\mathrm{b}}$ & $21.4^{\mathrm{b}}$ & $11.9^{\mathrm{c}}$ & 1.02 & 0.0001 \\
august 29 & $24.9^{\mathrm{a}}$ & $20.9^{\mathrm{b}}$ & $20.9^{\mathrm{b}}$ & $12.7^{\mathrm{c}}$ & 0.88 & 0.0001 \\
\hline
\end{tabular}

SHSB: whole soybean heated with steam, RSB: raw whole soybean, EXSB: extruded whole soybean, SE: standard error, p: significance, ${ }^{\text {abcd }}$ means in a row with different letters differ $(\mathrm{p}<0.05)$.

rial growth in supplemented animals ${ }^{6}$. In two (June 2 and July 3) out of four sampling, control animals had serum urea-N levels that suggested $\mathrm{N}$ limitation in the rumen. Serum urea-N concentrations also suggested less ruminal degradation of CP from EXSB.

All supplemented heifers had higher gain, hip height change, thoracic perimeter and body condition score change than the control group. Extruded soybean was better for animal performance, but the cost 
of extruding, and eventually transport, may offset this benefit compared to raw soybean. Because in Argentina there may be wide price variations between and within years, supplement cost and product price should be considered before deciding what supplement to use.

\section{REFERENCES}

1. Balbuena O, Kucseva CD, Rochinotti D, Slanac AL, Somma G, Schreiner JJ, Navamuel JM, Koza GA. 2002. Niveles de suplementación proteica invernal para recría de bovinos para carne en pasturas tropicales. Rev Arg Prod Anim 22 (Supl. 1): 16-18.

2. Balbuena O, Rochinotti D, Arakaki CL, Kucseva CD, Somma G, Slanac AL, Koza GA, Schreiner JJ, Navamuel JM. 2002. Suplementación proteica y consumo, cinética de la digesta y digestibilidad de heno de pasto estrella. Rev Arg Prod Anim 22 (Supl. 1): 18-19.

3. Balbuena O, Kucseva CD, Rochinotti D, Somma G, Flores AJ, Slanac AL, Schreiner JJ, Navamuel JM, Koza GA. 2003. Niveles de suplementación energético-proteica invernal para la recría de bovinos para carne en pasturas tropicales. 1. Afrechillo de trigo. Rev Arg Prod Anim 23 (Supl. 1): 19-20.

4. Goering HK, Van Soest PJ. 1970. Forage fiber analyses, Agricultural Handbook USDA No 379, Washington DC, 20 p.
5. Grummer RR, Rabelo E. 2000. Utilization of whole soybeans in dairy cattle diets. In: Soy in animal nutrition (Drackley JK ed.), Publ. Federation of Animal Science Societies, Savoy (Illinois, USA), p. 215-237.

6. Hammond AC. 1993. Use of blood urea nitrogen concentration to predict response to protein or energy supplementation in grazing cattle. Proc XVII Internat Grassland Congr, Rockhampton (Australia), p. 1989-1991.

7. Kucseva CD, Balbuena O, Slanac AL, Schreiner JJ, Somma G, Koza GA, Rochinotti D. 2001. Efecto de niveles de semilla de algodón en el suplemento sobre el consumo de heno en novillitos. Rev Arg Prod Anim 21: 5-6.

8. Moore JE. 1981. Procedure for determining voluntary intake and nutrient digestibility of hay with sheep, Publ Dept Anim Sci Univ Florida (Gainesville, USA), 8 p.

9. Rossi RL. 2004. Current status of the soybean production and utilization in Argentina. Proceedings III Congr Brasil de Soja (Londrina, Brasil), p. 38-49.

10. SAS Institute Inc. 1987. SAS/STAT guide for personal computers, $6^{\circ}$ ed., SAS Institute, Cary, NC, USA.

11. Titgemeyer EC. 2000. Soy by-products as energy sources for beef and dairy cattle. In: Soy in animal nutrition (Drackley JK ed.), Publ. Federation of Animal Science Societies, Savoy (Illinois, USA), p. 238-257.

12. Van Keulen J, Young BA. 1977. Evaluation of acid insoluble ash as a natural marker in ruminant digestibility studies. J Anim Sci 44: 282-287. 